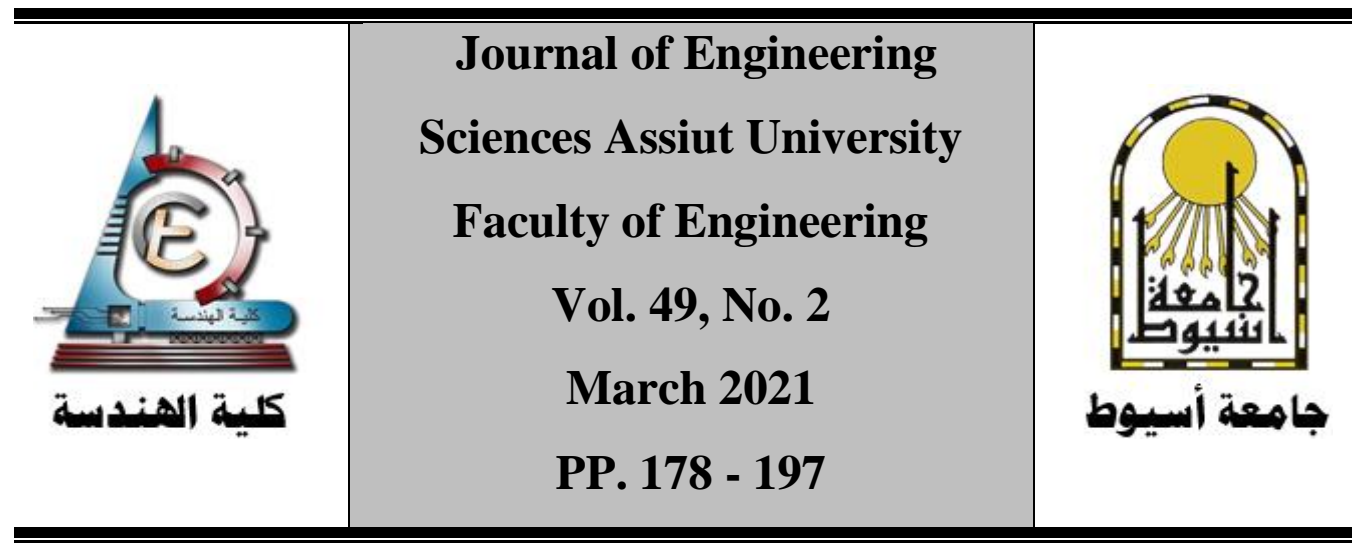

\title{
PERFORMANCE OF FLY ASH CONCRETE AGAINST SULFATE ATTACK
}

\author{
Mohamed ANWAR ${ }^{1}$, Aly A. Makhlouf ${ }^{2}$ \\ ${ }^{1}$ Professor, Construction Research Institute, NWRC, Delta-Barrage, Egypt \\ ${ }^{2}$ Assistant Professor, Construction Research Institute, NWRC, Delta-Barrage, \\ Egypt,amakhlouf@yahoo.com
}

Received 11 December 2020; Revised 15 February 2021; Accepted 16 February 2021

\begin{abstract}
In this research, the effect of using fly ash on sulfate resistance of concrete was investigated. Studied mixes in this work are part of a research project that investigates the influence of using binary and ternary cementitious materials on different properties of concrete. In this paper, three groups of concrete mixtures were studied; each group includes three mixes. The concrete mix proportions were adjusted to produce concrete with certain values of air content and slump. The used water / binder material ratios were $0.4,0.5$ and 0.6. Concrete samples were cured in water until testing day. After 28 days of water curing, samples were immersed in sodium sulfate solution for 6 months. The hardened concrete properties were investigated through destructive and nondestructive tests at various samples' age. The research results showed that using fly ash improved the resistance of concrete to sulfate attack. Therefore, with considerable proportions, using fly ash in concrete industry improves the performance of concrete for sulfate resistance and its durability.
\end{abstract}


Keywords: Concrete, Sulfate resistance, Water to binder material ratio, Portland cement, Fly ash.

\section{Introduction}

Portland cement is the essential binding agent in concrete, which has many advantages to use as a construction material such as lower cost (relative to polymers, aluminum, or steel), and durability. Materials of natural origin such as industrial by-products or volcanic ash like pulverized fuel ash and ground granulated blast furnace slag, have been widely used as partial replacement of Portland cement in concrete. The advantages of using these materials are improved technological properties, low cost, and reduction of waste accumulation [1]. Coalburning power plants produce fly ash. Fly ash is widely used as a cementitious and a pozzolanic material in concrete. The properties of concrete are improved because of using of fly ash in concrete [2].

High-strength concrete has been used in civil engineering work to reduce the sizes of structure members in high-rise buildings. A 28-day concrete compressive strength more than $41 \mathrm{MPa}$ can be considered as high-strength concrete according to ACI Committee 363. Generally, by using superplasticizer and supplementary cementing materials such as fly ash, high-strength concrete can be made due to reducing the waterbinder ratio and creating extra strength by pozzolanic reaction [3]. The harmful chemicals of ground water, effluents of industry materials and sea water cause reinforcing steel corrosion due to its exposure. Concrete loses its strength due to calcium, sodium, and magnesium sulfates attack [4]. Anwar [5] reported that the resistance of concrete to sulfate attack was improved with using considerable amount of cementitious by-product such as silica fume, slag, and fly ash. The use of fly ash reduces heat generation, prevents expansion, and gives better durability in concrete $[6,7]$. The use of fly ash on concrete improved the sulfate resistance due to the reduction in the $\mathrm{C} 3 \mathrm{~A}$ and the $\mathrm{Ca}(\mathrm{OH})$ 2 [8].

The normal replacement percent of Portland cement by fly ash on concrete is 15 to $25 \%$ and can be $35 \%$ in some special works. The concrete performance is improved by using of fly ash, through strength increasing with time and permeability reduction, which enhances the 
durability of concrete [9]. Concrete loses strength with time due to gradually deterioration resulting from exposition to the surroundings sulfate-bearing water. It is believed that the reaction of sulfate ions with calcium aluminate and calcium hydroxide hydrate in concrete arise the formation of ettringites and/or gypsum, which causes the expansion and deterioration of concrete. Replacement of cement by fly ash improves the sulfate resistance due to the consumption of the free lime, which reduces permeability and reduces the number of reactive aluminates available [9].

The chemical and physical properties of fly ash and Portland cement are main factors influence the performance of fly ash in concrete [10]. However, the type of fly ash affects concrete resistance to sulfate attack where Class F fly ash shows better improvement of concrete sulfate resistance than Class $C$ fly ash [11]. In addition, Antiohos [12] reported that incorporating fly ashes (high and low calcium) in concrete leads to cheap concrete production and friendly environmental concrete.

In this work, attempts were done to cover the effect of change in water to binder ratio, cementitious material content and replacement percent of Portland cement with fly ash on the concrete properties. Furthermore, in this research, the relationships between the results of destructive (compressive strength) and non-destructive (pulse velocity and dynamic elastic modulus) were established for the studied concrete mixtures after sulfate exposure.

\section{Experimental Procedure}

The materials were selected from commercially available materials in Japan. Two types of chemical admixtures are used; the first one is high performance superplasticizer $(\mathrm{AD}$, high range water reducing processing air entraining) and the second is air entraining agent (AE). The specific gravity of sand is 2.55 and it has $1.23 \%$ water absorption. The used gravel has a $15 \mathrm{~mm}$ and $20 \mathrm{~mm}$ size with 2.56 specific gravity and water absorption of $2.5 \%$. The properties of Portland cement comply with Japanese Industrial Standard (JIS). The properties of Portland cement and fly ash listed in Table 1.

The concrete mixtures prepared in this research work were divided to three groups named I, II, and III. Each group involves three concrete mixtures with different water / binder material ratio. The binder 
material content (BMC) is 410,330 , and $280 \mathrm{~kg} / \mathrm{m}^{3}$ and values of water/binder material ratios $(\mathrm{W} / \mathrm{B})$ are $0.4,0.5$ and 0.6 . The used sand/aggregate ratio is 0.4 . The used percentages of fly ash are $15 \%$ and $25 \%$ as a replacement ratio of ordinary Portland cement. The concrete mixtures designed to produce concrete with slump of $10 \pm 2$ $\mathrm{cm}$ and air content of $4 \pm 1 \%$. Table 2 summarizes the details of studied concrete mixtures. The slump, unit weight and air content were measured for fresh concrete. The compressive strength, pulse velocity and dynamic elastic modulus measured for hardened concrete at 3, 7, 28, 90 and 180 days while tensile strength and static elastic modulus were measured only at 28 days.

Table 1: Properties of Portland cement and fly ash.

\begin{tabular}{|l|c|c|}
\hline \multicolumn{1}{|c|}{ Constituents } & Ordinary Portland Cement (OPC) & $\begin{array}{c}\text { Fly Ash } \\
\text { (FA) }\end{array}$ \\
\hline Specific gravity & 3.16 & 2.32 \\
Surface area $\left(\mathrm{cm}^{2} / \mathrm{g}\right.$ ) & 3310 & 3910 \\
Loss on ignition, $\mathrm{L.O} . \mathrm{I}$ & 2.05 & 1.95 \\
Silicon dioxide, $\mathrm{SiO} 2$ & 22.0 & 45.0 \\
Magnesium oxide, $\mathrm{MgO}$ & 1.12 & N/A \\
Sulfur trioxide, $\mathrm{SO}_{3}$ & 2.13 & N/A \\
Chloride Ion, $\mathrm{Cl}^{-}$ & 0.011 & N/A \\
\hline
\end{tabular}

Table 2: Details of studied concrete mixtures.

\begin{tabular}{|c|c|c|c|c|c|c|c|c|c|c|}
\hline \multirow{2}{*}{\multicolumn{2}{|c|}{$\begin{array}{c}\text { Group No. } \\
\text { Mix No. }\end{array}$}} & \multicolumn{3}{|c|}{ I } & \multicolumn{3}{|c|}{ II } & \multicolumn{3}{|c|}{ III } \\
\hline & & 1 & 2 & 3 & 4 & 5 & 6 & 7 & 8 & 9 \\
\hline Sand & \multirow{8}{*}{ 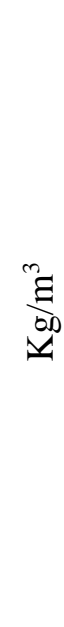 } & 680 & 672 & 668 & 704 & 699 & 695 & 718 & 713 & 709 \\
\hline $\begin{array}{l}\text { Gravel } \\
(20 \mathrm{~mm})\end{array}$ & & 512 & 506 & 503 & 530 & 526 & 523 & 540 & 537 & 534 \\
\hline $\begin{array}{c}\text { Gravel } \\
(15 \mathrm{~mm})\end{array}$ & & 510 & 504 & 501 & 528 & 524 & 521 & 538 & 534 & 532 \\
\hline Water & & \multicolumn{3}{|c|}{164} & \multicolumn{3}{|c|}{165} & \multicolumn{3}{|c|}{168} \\
\hline OPC & & 410 & 348.5 & 307.5 & 330 & 280.5 & 247.5 & 280 & 238 & 210 \\
\hline Fly ash & & 0 & 61.5 & 102.5 & 0 & 61.5 & 102.5 & 0 & 61.5 & 102.5 \\
\hline $\mathrm{AD}$ & & 3.895 & 3.690 & 3.28 & 3.960 & 3.63 & 3.300 & 3.36 & 2.94 & 2.66 \\
\hline $\mathrm{AE}$ & & 1.025 & 3.075 & 3.69 & 1.155 & 3.63 & 3.960 & 1.12 & 3.36 & 3.64 \\
\hline
\end{tabular}


Batching of materials into the mixer was made in the sequence: gravel and sand followed by binder material (mixed well) the mixing time was adjusted for 3 minutes, all dry materials were mixed for 60 seconds followed by adding water with admixture within 30 seconds, then the mixing time continues until the end of 3 minutes. From each mix, fifteen (15) specimens (water curing) were cast for testing of compressive strength, pulse velocity, dynamic elastic modulus, and static elastic modulus. Moreover, three specimens from each mix were cast for testing of tensile strength. The specimens were compacted using a vibrator and de-molded after 24 hours. The water curing starting until time of testing.

To study the effect of adding fly ash with Portland cement on the resistance of concrete to sulfate attack, after 28-day water curing, nine (9) samples from each mix exposed to a 5\% sodium sulfate solution up to 6 months. Then, compression, pulse velocity and dynamic elastic modules tests performed after 1, 3, and 6 months. Sample preparation, testing procedures, equipment, and apparatus used describe in detail in ref. [9]. The results in this work are average of three tests samples

\section{Properties of Fresh Concrete}

As mentioned above, the measured properties of fresh concrete include slump, air content (the concrete mixtures designed to achieve slump of $10 \pm 2 \mathrm{~cm}$ and air content of $4 \pm 1 \%$ ) and unit weight. Dose of the used chemical admixtures (high performance superplasticizer and air entraining agent) were changed to achieve the designed values of slump and air content. The measured values of slump, air content and unit weight are shown in Figures 1, 2 and 3, respectively.

During proportion and mixing the concrete mixtures, it is noticed that fly ash mixtures need high dose of the air-entraining agent to achieve the designed air content. Concerning the superplasticizer, OPC mixtures need higher dose than those of fly ash ones as listed in Table 1. 


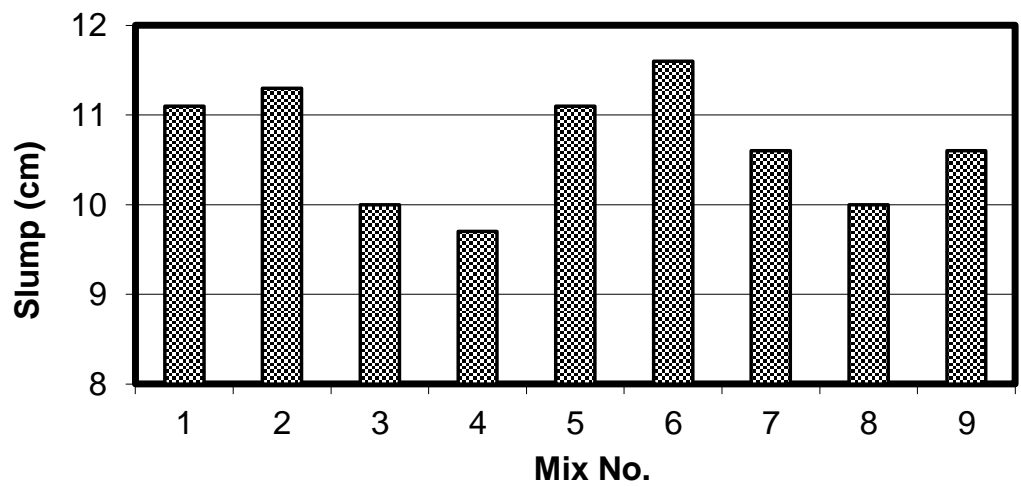

Figure 1: Slump of fresh concrete.

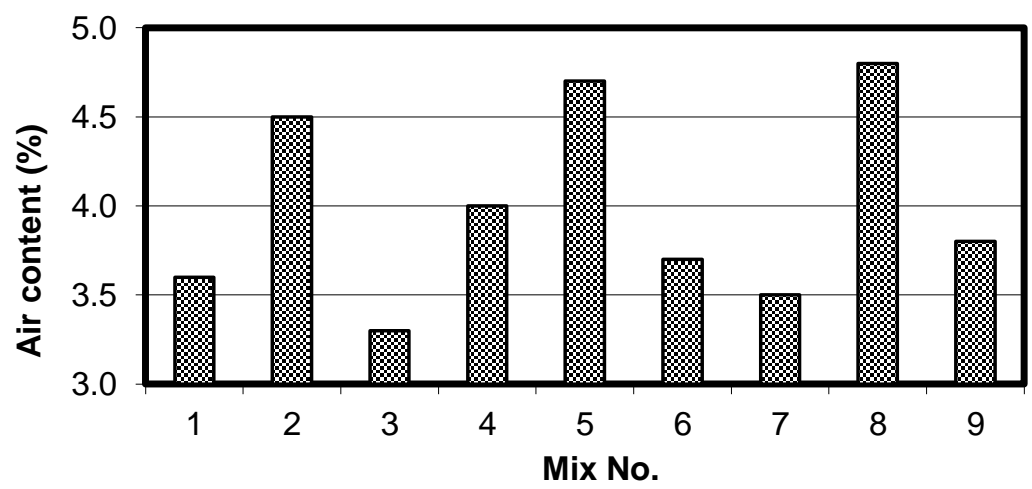

Figure 2: Air content of fresh concrete.

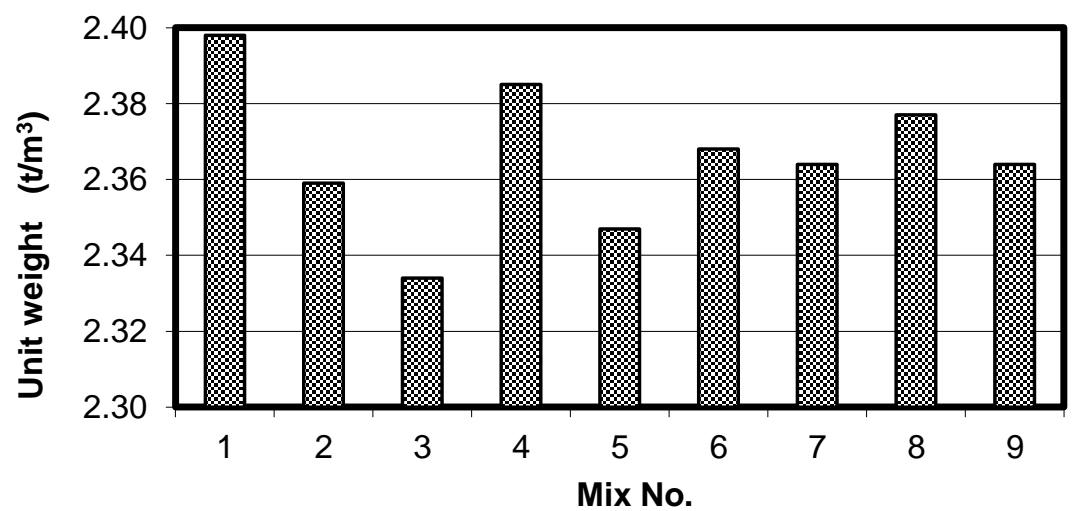

Figure 3: Unit weight of fresh concrete. 
The measured values of slump and air content fall within the designed range, i.e., all measured slumps are $10 \pm 2 \mathrm{~cm}$ and air content of $4 \pm 1$ $\%$. Moreover, change in the replacement percent of fly ash results in changing the unit weight of produced concrete as shown in Figure 3. This attributed to change in the specific gravity of the Portland cement and fly ash as well as the used water/binder material ratio.

\section{Properties of Hardened Concrete}

Figure 4 shows results of compressive strength up to age of 180 days. For first group I (Figure 4-a), concrete mixtures with fly ash show lower compressive strength values up to 7 days while results after 90 days are equivalent or slightly less compressive strength than those of the corresponding mixtures made with OPC. For mixes of groups II (Figure 4-b) and III (Figure 4-c), the results of fly ash concrete are lower than OPC concrete until 180 days. Generally, the obtained data of all groups show that the compressive strength is inversely proportions to increasing in the $\mathrm{w} / \mathrm{b}$ ratio and decreasing in binder materials content for the investigated concrete mixtures. Furthermore, the rates of compressive strength development up to 180 days of concrete mixes are presented in Figure 5. The obtained results of fly ash concrete show lower rate of strength gain than OPC concrete until 28 days. After, 28 days, strength gain shows slightly differences between OPC and fly ash mixes.

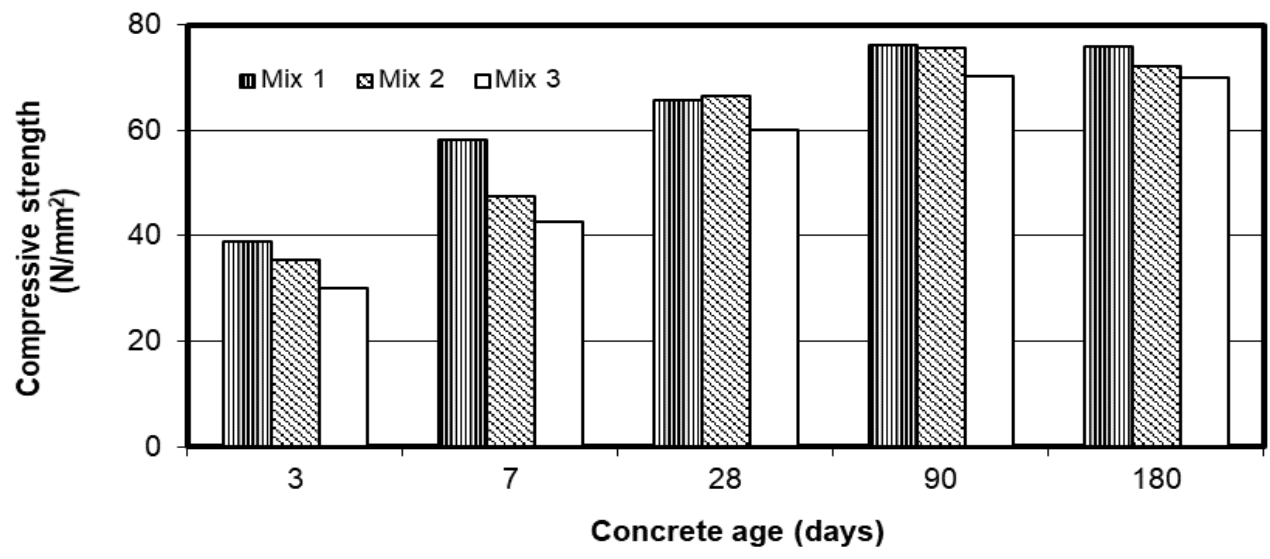

Figure 4-a: Compressive strength of group I. 


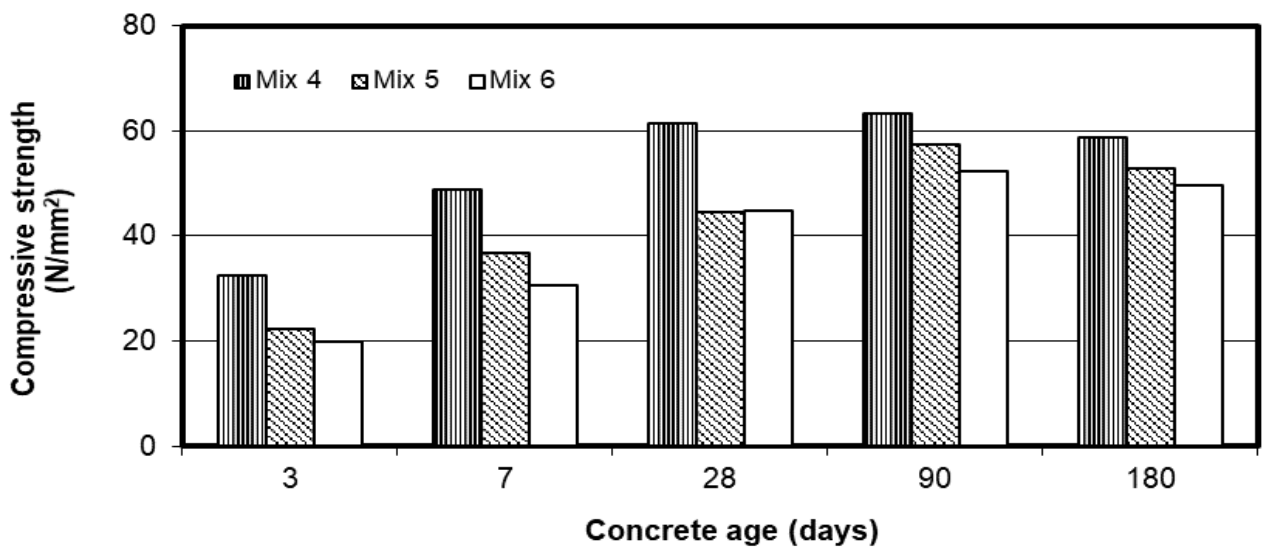

Figure 4-b: Compressive strength of group II.

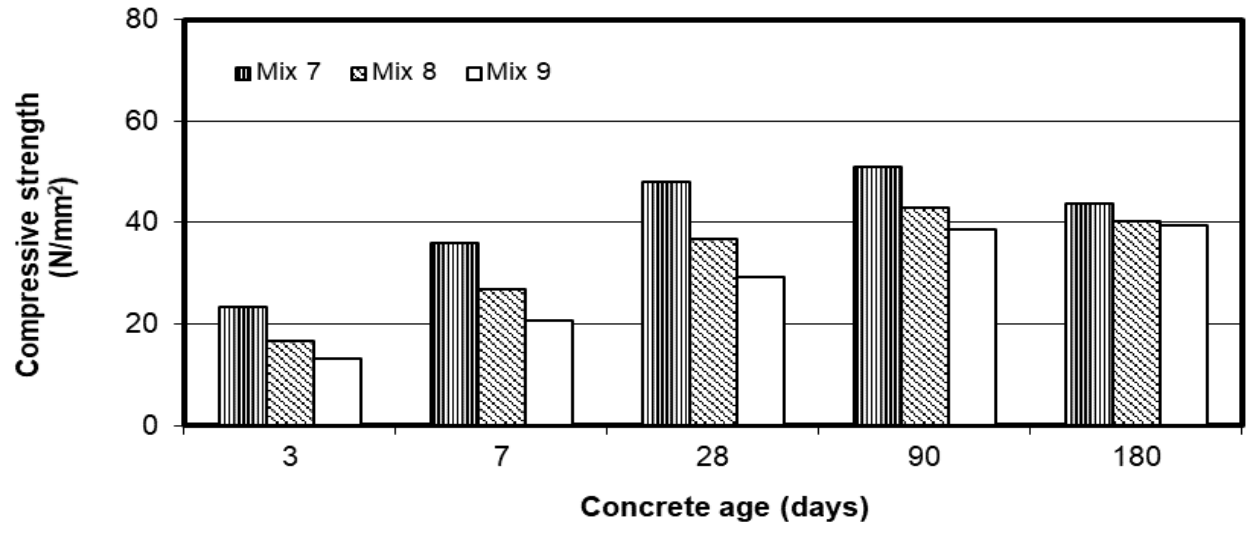

Figure 4-c: Compressive strength of group III.

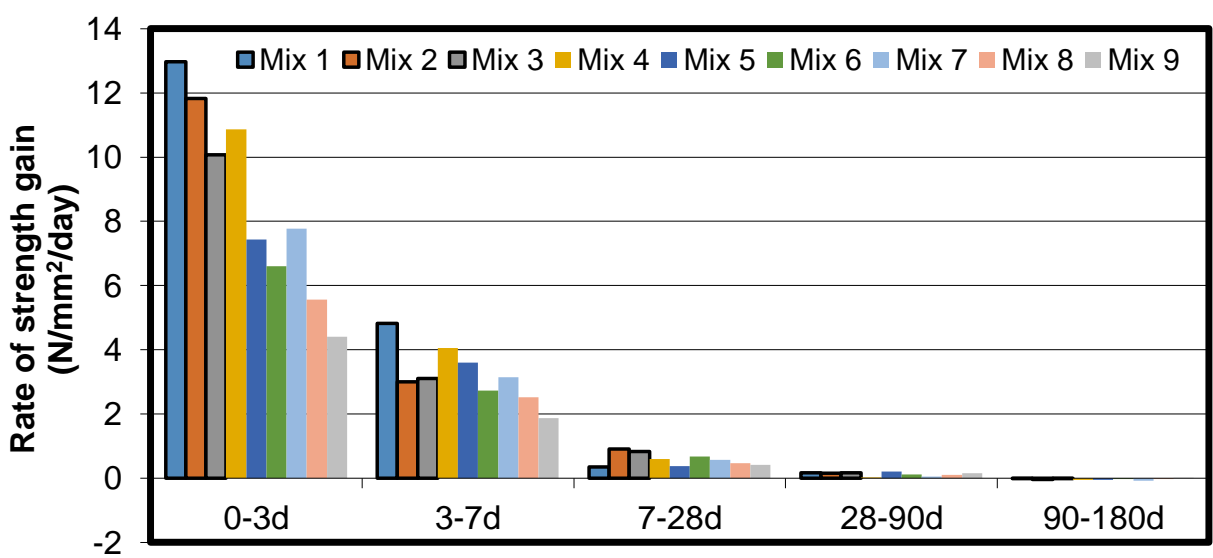

Periods (days)

Figure 5: Rate of compressive strength development. 


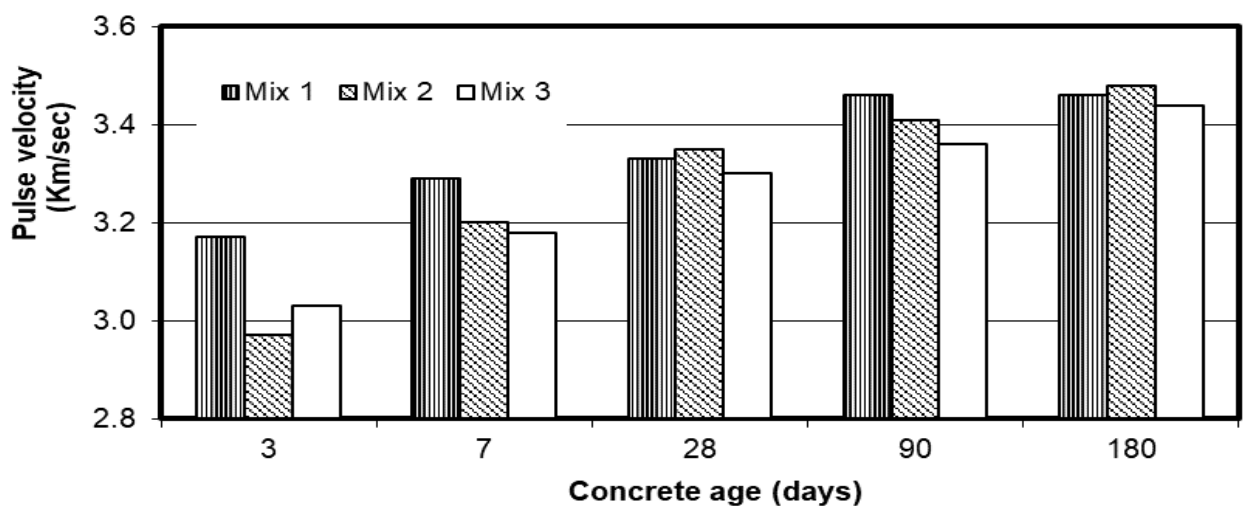

Figure 6-a: Pulse velocity of group I.

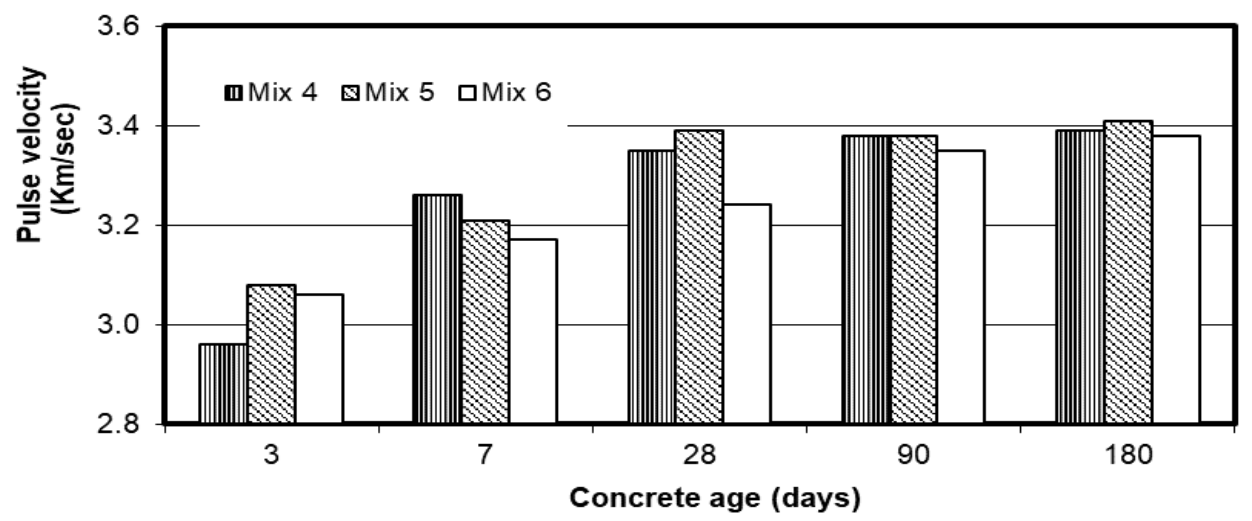

Figure 6-b: Pulse velocity of group II.

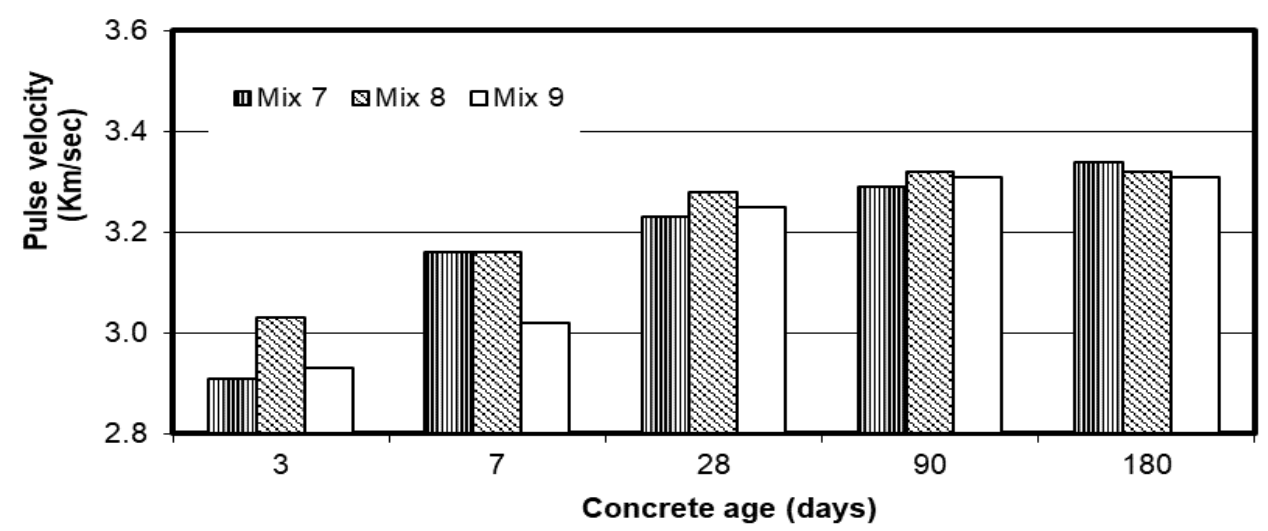

Figure 6-c: Pulse velocity of group III. 


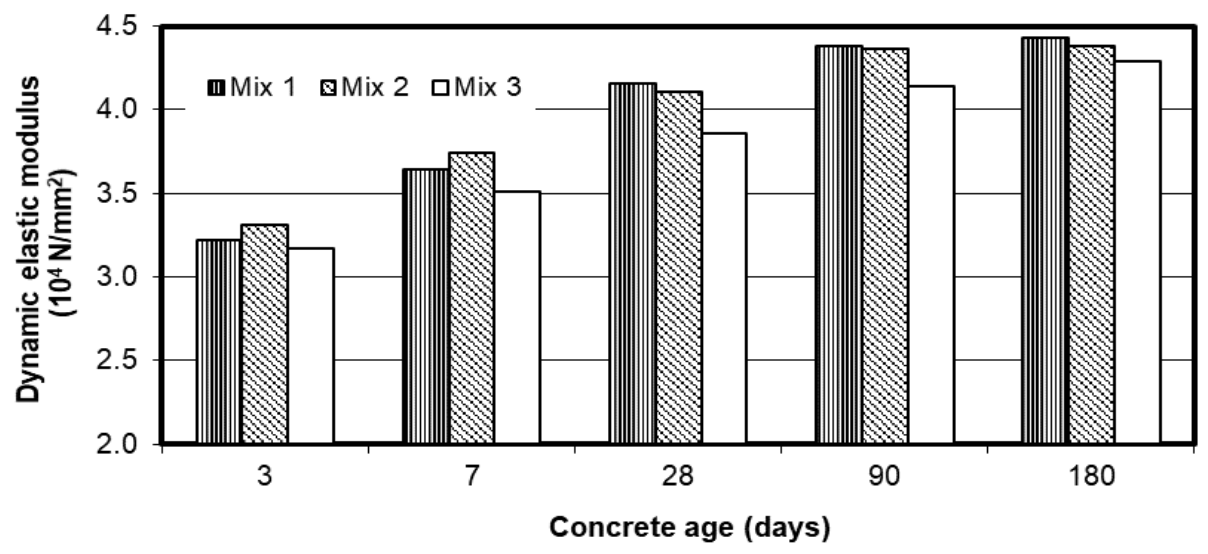

Figure 7-a: Dynamic elastic modulus of group I.

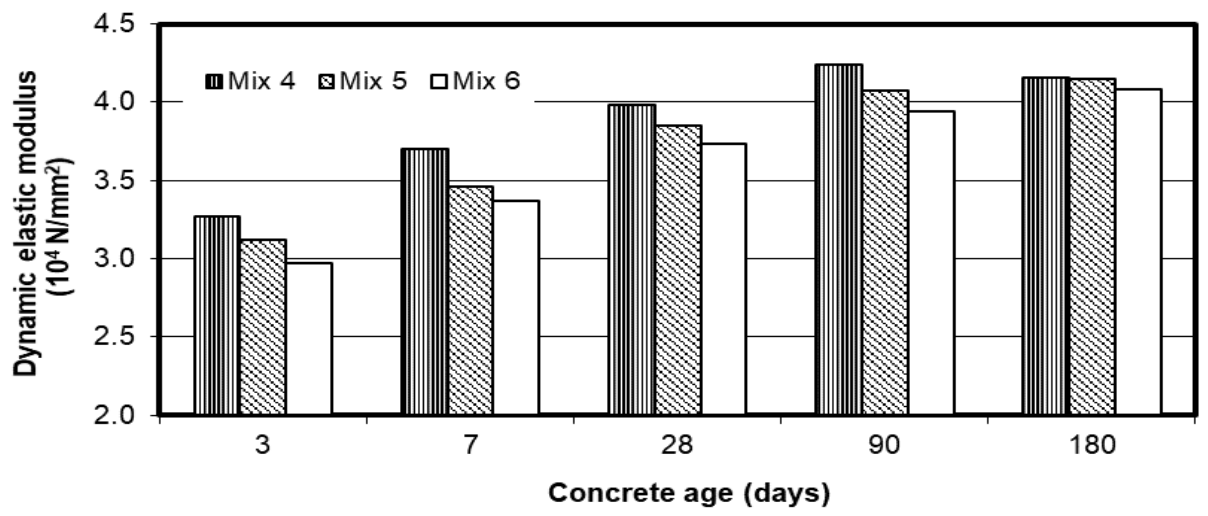

Figure 7-b: Dynamic elastic modulus of group II.

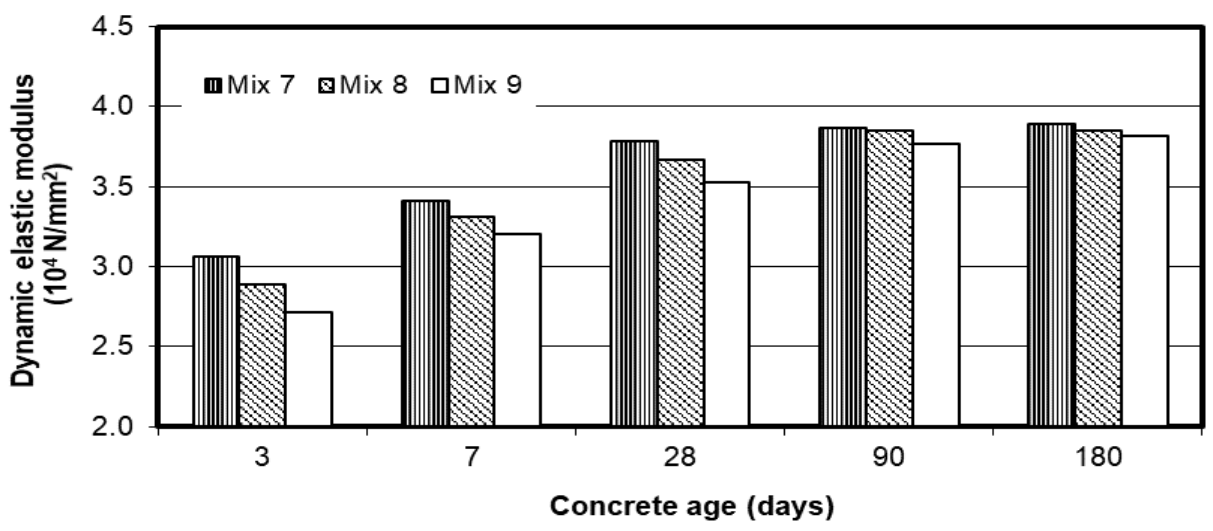

Figure 7-c: Dynamic elastic modulus of group III. 


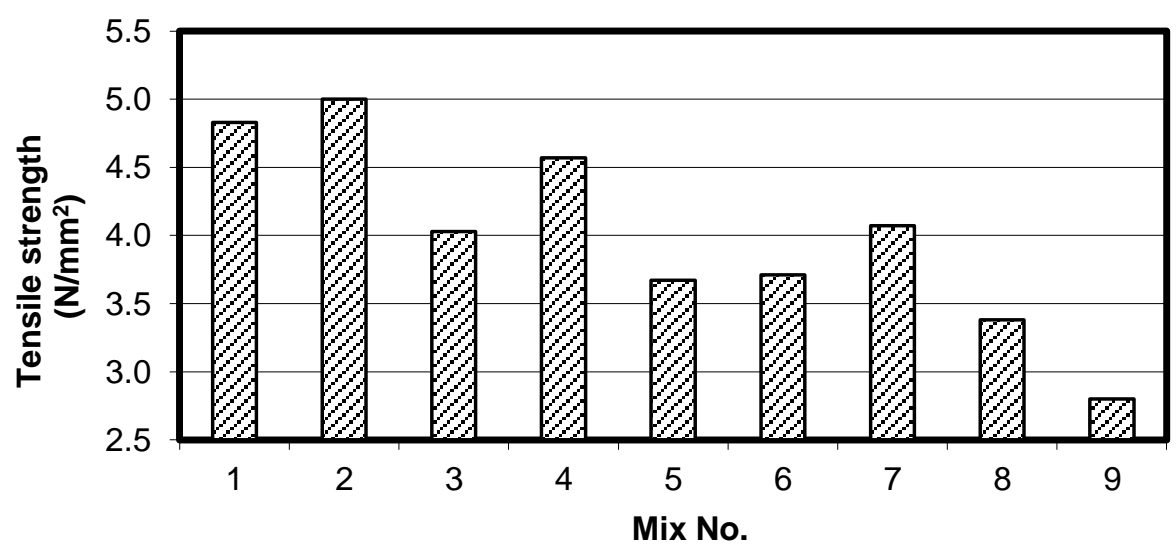

Figure 8: Tensile strength of concrete.

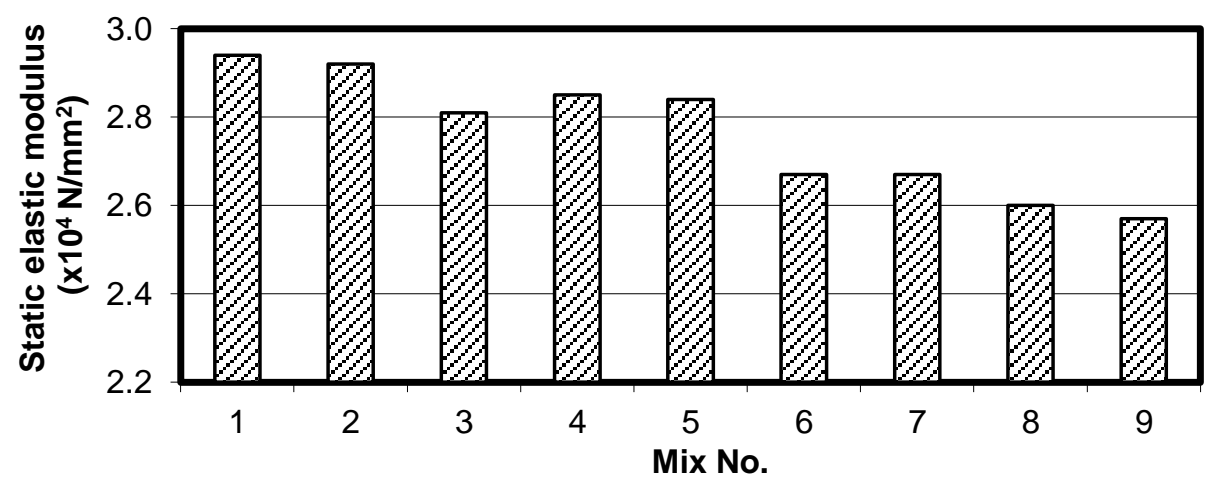

Figure 9: Measured Static elastic modulus.

Figure 6 and Figure 7 show pulse velocity and dynamic elastic modulus results until 180 days. The obtained data show that pulse velocity and dynamic elastic modulus of fly ash concrete mixtures are equivalent to OPC concrete mixtures at ages 28,90 and 180 days. While the obtained results decrease with decreasing in the binder materials content and increasing in the $\mathrm{w} / \mathrm{b}$ ratio.

Figure 8 and Figure 9 represent results of tensile strength and static elastic modulus at 28 days. The results of the fly ash mixes showed tensile strength and the static elastic modulus lower than OPC mixes. Moreover, the results of the tensile strength and static elastic modulus decreased with increasing in water/binder ratio and decreasing in binder materials content. 


\section{Sulphate Resistance}

Figure 10 presents results of measured compressive strength of concrete after immersion in 5\% of sodium sulfate solution and results of compressive strength at 28 -days of water curing (28-W) without sulfate, i.e., before the immersion process. From results of groups I (Figure 10-a), II (Figure 10-b), and III (Figure 10-c) until 6 months of immersion, it is appeared that strength gain due to the hydration of binder materials is higher than strength loss due to the immersion in 5\% sodium sulfate solution as indicated in Figure 11. Furthermore, fly ash mixes show compressive strengths lower than those of OPC. Moreover, mixes of fly ash concretes of $15 \%$ and $25 \%$ show almost the same results of compressive strength after immersion until 6 months. As mentioned above, the decreasing in binder materials content and increasing in $\mathrm{w} / \mathrm{b}$ ratio led to decreasing measured compressive strength.

From the reported results, after 1, 3, 6 months of immersion, fly ash mixes exhibit better performances than the reference concrete of OPC at all testing ages after exposure to sulphate. The visual inspection of tested samples exposed to sulfate for 6 months indicated no detectable trace of deterioration caused by the sulfate attack within 6 months of exposure

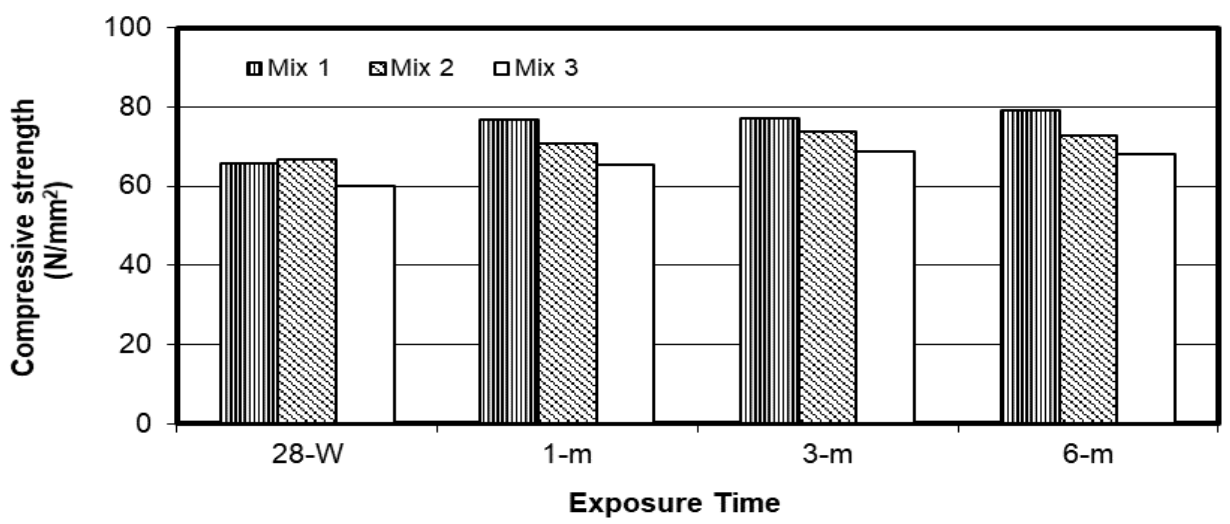

Figure 10-a: Compressive strength after immersion of group I. 


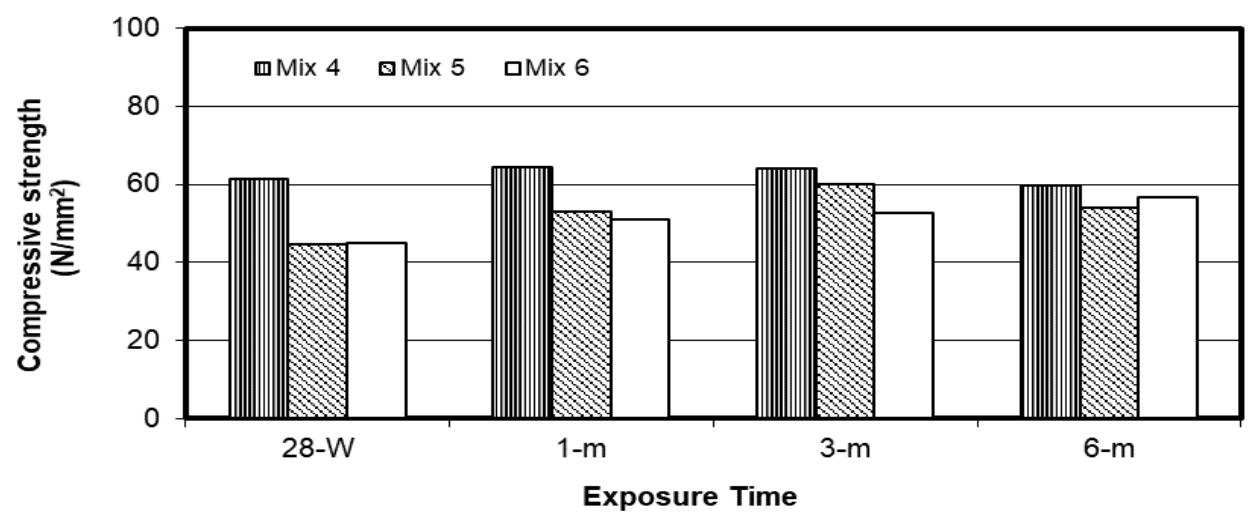

Figure 10-b: Compressive strength after immersion of group II.

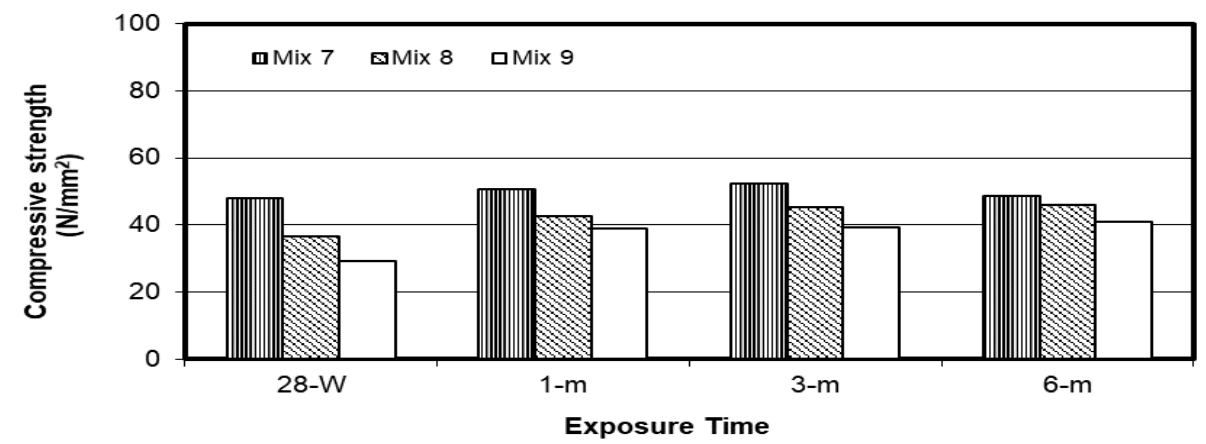

Figure 10-c: Compressive strength after immersion of group III.

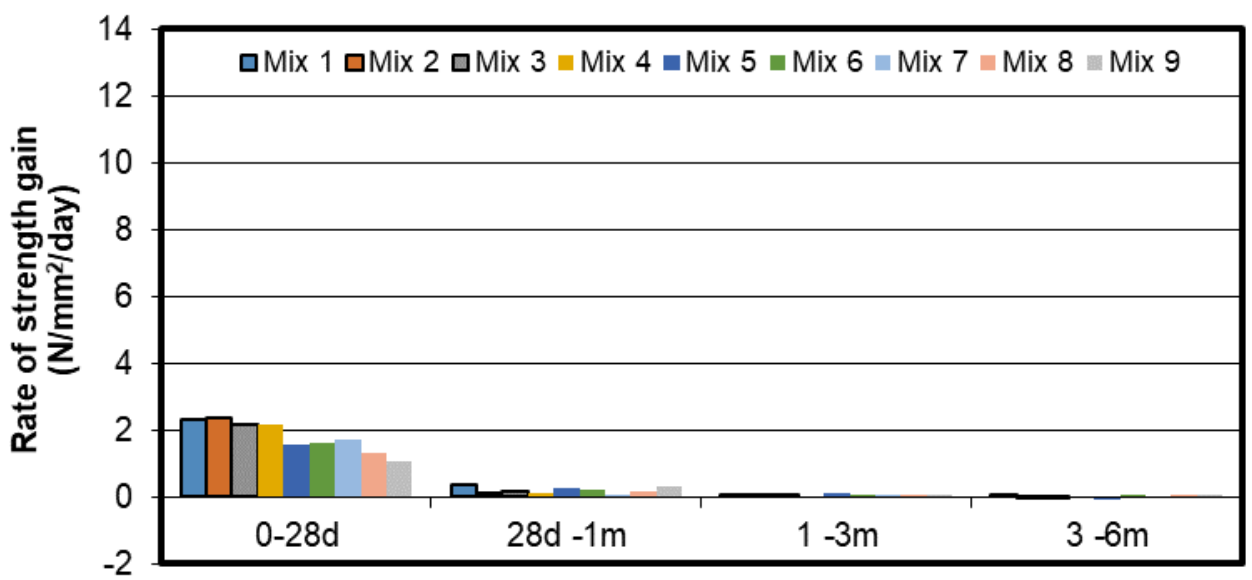

\section{Periods (days)}

Figure 11: Rate of compressive strength development after immersion 


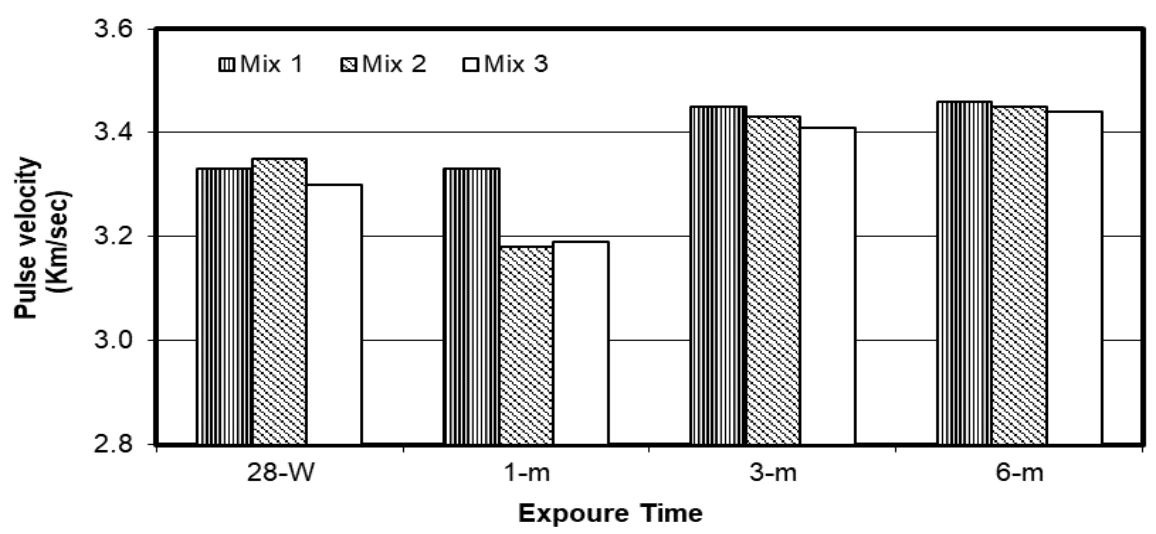

Figure 12-a: Pulse velocity after immersion of group I.

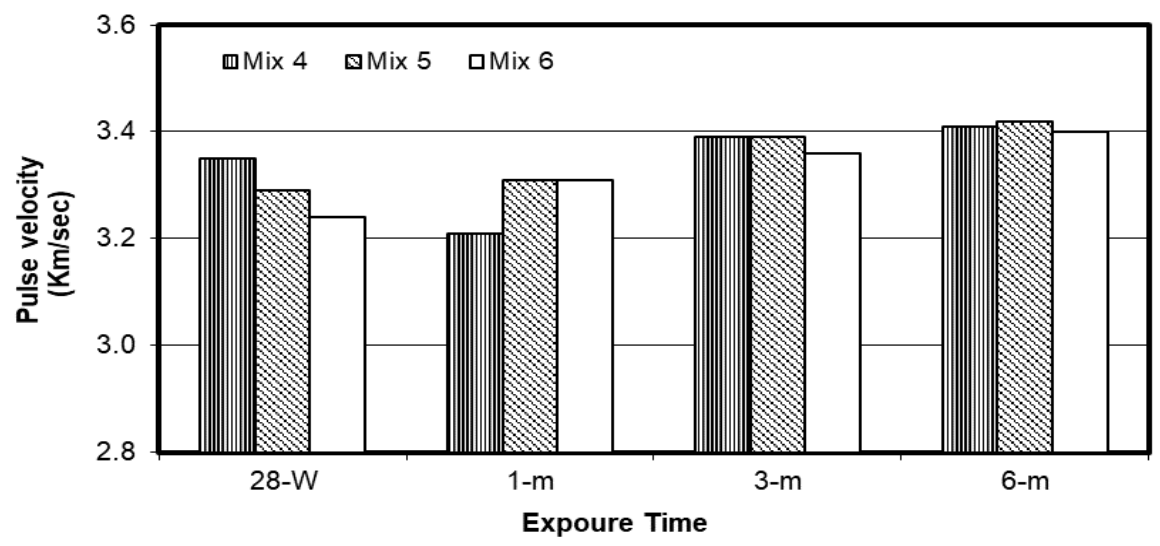

Figure 12-b: Pulse velocity after immersion of group II.

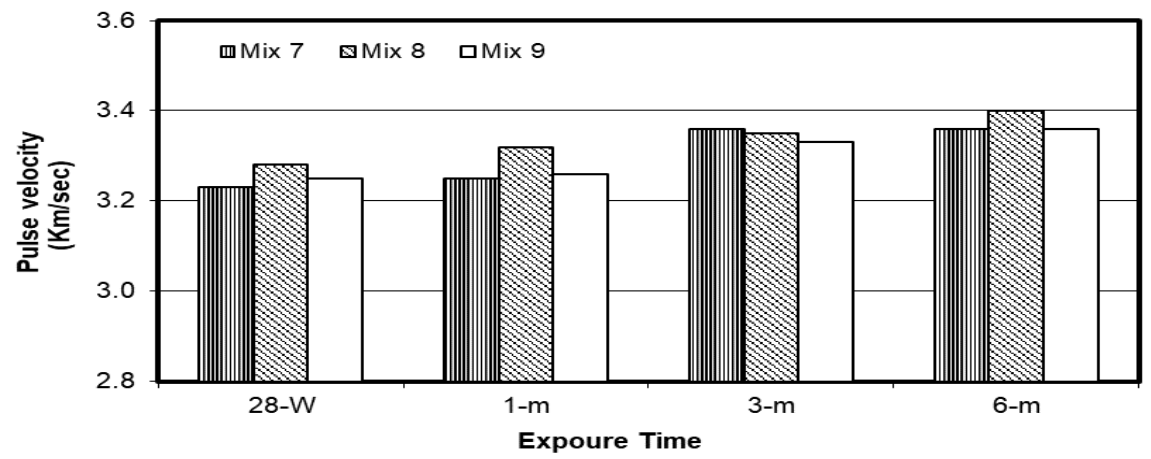

Figure 12-c: Pulse velocity after immersion of group III. 


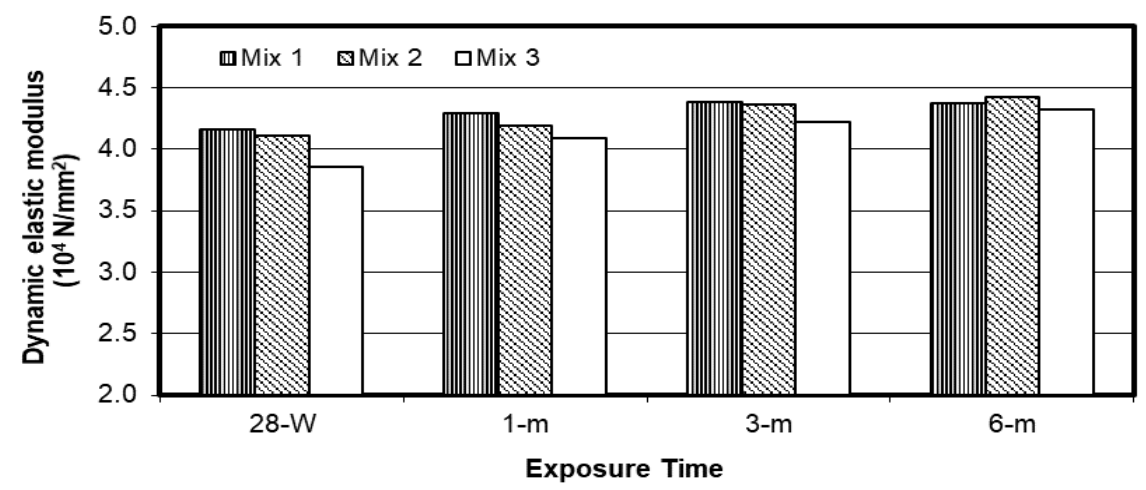

Figure 13-a: Dynamic elastic modulus after immersion of group I.

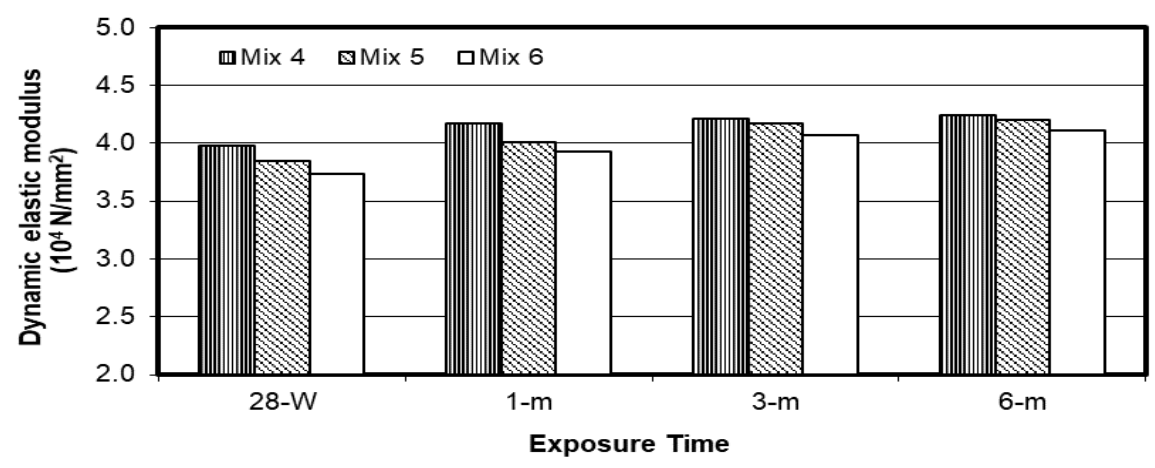

Figure 13-b: Dynamic elastic modulus after immersion of group II.

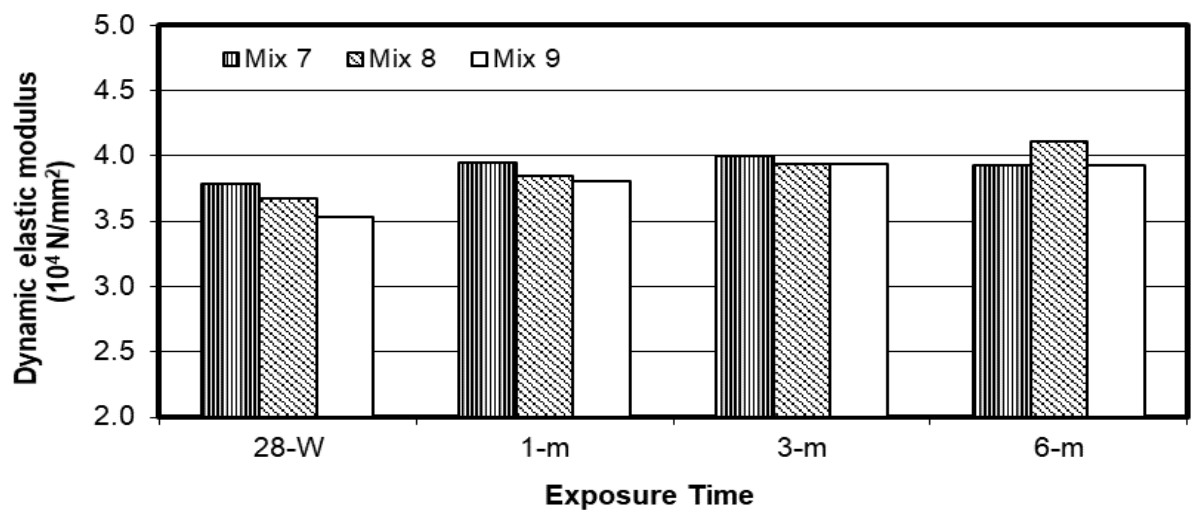

Figure 13-c: Dynamic elastic modulus d after immersion of group III. 


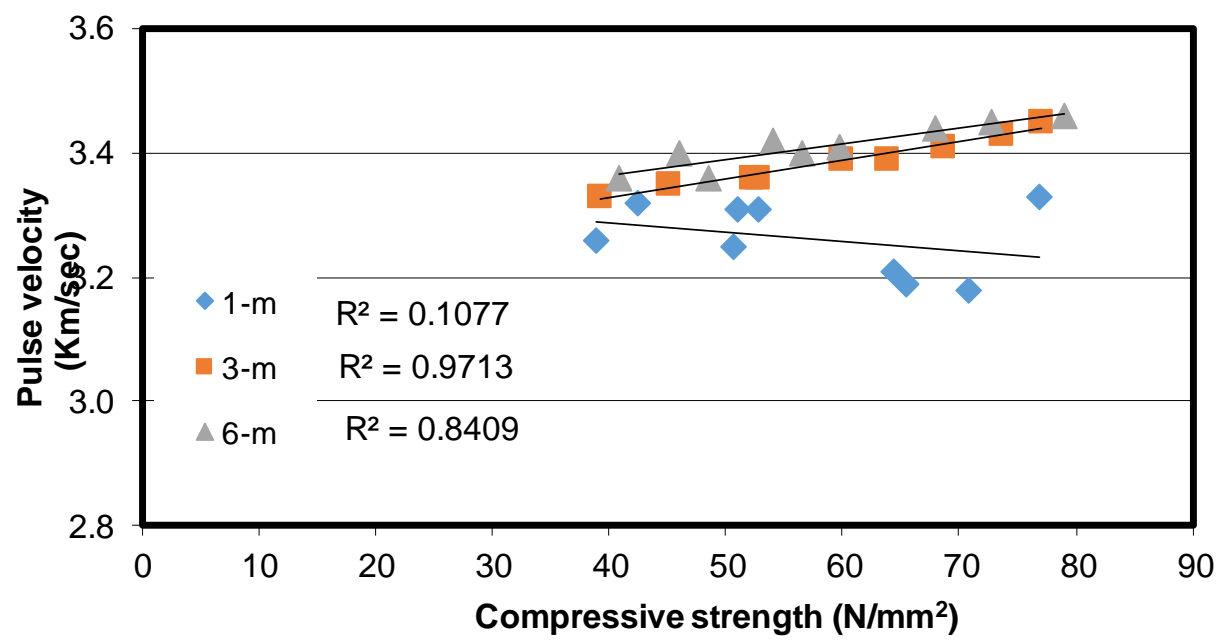

Figure 14: Relationship between pulse velocity and compressive strength after immersion

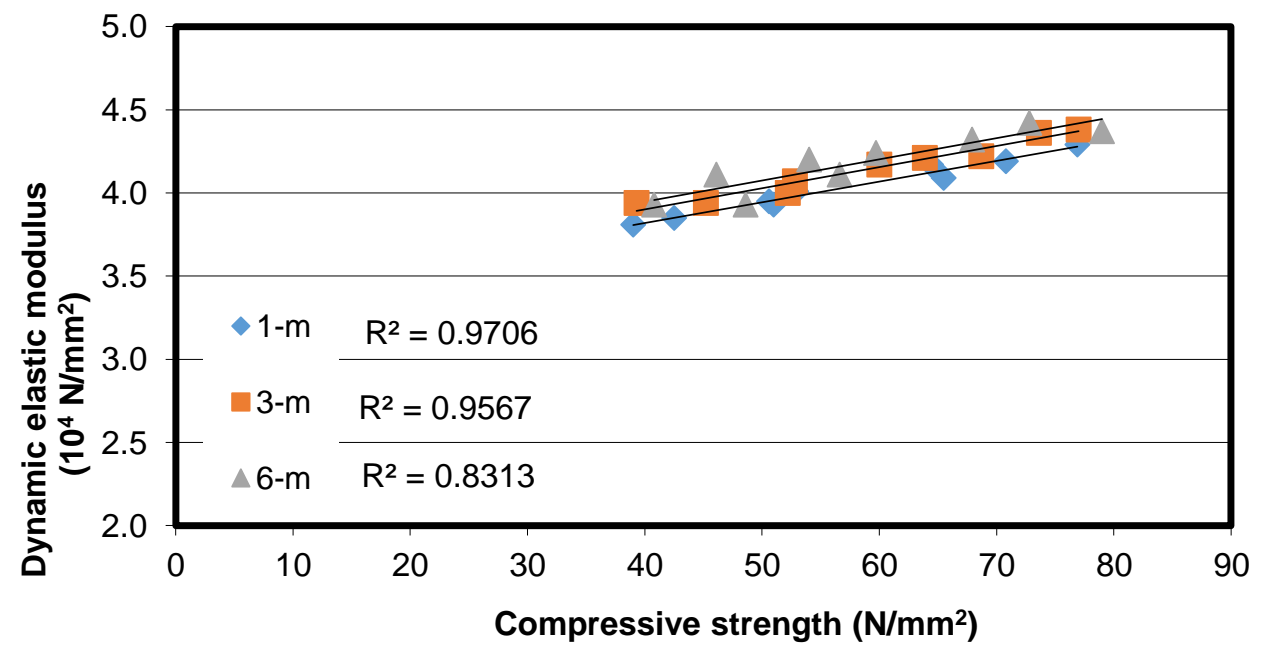

Figure 15: Relationship between dynamic elastic modulus and compressive strength after immersion

Figure 12 shows the effect of immersion period on pulse velocity through studied concrete specimens. Figure 12 reveals that the pulse velocity of the studied concrete specimens after 1 month is equivalent to that before immersion. While after 3 and 6 months of immersion, the results increase with increasing the immersion period. The pulse velocity results show the same trend of measured compressive strength, 
where the decreasing in binder materials content and increasing in $\mathrm{w} / \mathrm{b}$ ratio led to decreasing in the measured pulse velocity.

Figure 13 depicts the effect of immersion period on the measured dynamic elastic modulus values for the studied mixes. Generally, measured values indicate that with increasing the immersion period until 6 months, the values of dynamic elastic modulus slightly increase. The dynamic elastic modulus values of the studied three groups of concrete are relatively comparable after 1,3 and 6 months of the immersion periods. Further, the measured value of the pulse velocity and dynamic elastic modulus (nondestructive tests) show a good agreement with the compressive strength as noticed in Figure 14 and Figure 15. Therefore, it can recommend using these nondestructive tests to compare, quality check, and evaluate deterioration degree of concrete due to the exposure to severe conditions.

\section{Conclusions}

1. Combinations of OPC with 15 to $25 \%$ fly ash show satisfactory performance in both fresh and hardened concrete. Such combinations produce concrete with generally good properties, where fly ash concrete with replacement percent $(15 \%, 25 \%)$ of cement shows equivalent or slightly less compressive strength than those of the corresponding mixtures made with OPC after 90 days.

2. Concrete with fly ash showed good sulfate resistance during 6 months of exposure to the $5 \%$ sodium sulfate solution and visual inspection of tested samples exposed to sulfate for 6 months indicated no deterioration appears.

3. The measured properties in the work are inversely proportions to increasing in the w/b ratio and decreasing in binder materials content for the investigated concrete mixtures.

4. Depending on the results of the research, it is recommended to use the nondestructive tests (pulse velocity and dynamic elastic modulus) for comparing, checking the quality of concrete and evaluate the deterioration degree of concrete due the exposure to severe conditions.

5. Many environmental benefits can be gained from replacing up to $25 \%$ of cement content in the concrete by fly ash, like reduction of greenhouse gases (GHG). As cement industry in Egypt is 
responsible of air pollution by GHG emission with 17-million-ton $\mathrm{CO} 2 \mathrm{e} / \mathrm{year}$, the reduction in cement production causes the reduction of GHG emission by about 6-million-ton $\mathrm{CO} 2 \mathrm{e} / \mathrm{year}$.

6. Another benefit can be gained as achieving an environmentally disposing of the by-products (fly ash) where the bad practices of by-products disposal causing more GHG emissions. Moreover, following the sustainable development concept, using the byproduct natural cement like materials and reduction of cement production conserve the natural resources from depletion and meet the future demands for more concrete.

\section{References}

[1] Escalante-Garcia, J.-I., Sharp, J.H "The Chemical Composition and Microstructure of Hydration Products in Blended Cements ", Cement \& Concrete Composites, 26 (8), 967-976, 2004.

[2] Chai J., Kraiwood K., Vanchai S., Theerarach L. " Use of Ground Coarse Fly Ash as a Replacement of Condensed Silica Fume in Producing HighsStrength Concrete", Cement and Concrete Research, 34 (4), 549-555, 2004.

[3] ACI Committee 363 "State of the Art Report on High-Strength Concrete", ACI 363R-92, ACI Manual of Concrete Practice: Part I, American Concrete Institute, Detroit, 2000.

[4] Wee T.H., Suryavanshi A.K., Wong S.F., Rahman A.K. "Sulfate Resistance of Concrete Containing Mineral Admixtures", ACI Material Journal, 97 (5), 536-549, 2000.

[5] M. Anwar. "Effect of Cementitious Materials on Concrete against Sulfate Attack. Engineering Research Journal", Helwan University, Faculty of Engineering, Mataria, Cairo, Egypt, Vol. 99, C92-C104, 2005.

[6] Poon, C. S., Lam, L. and Wong, Y. L. "A Study on High-Strength Concrete Prepared with Large Volumes of Low Calcium Fly Ash", Cement and Concrete Research, Vol. 30, 2000, pp. 447-445, 2000.

[7] Shehata, M. H. and Thomas, M. D. A. "The Effect of Fly Ash Composition on the Expansion of Concrete due to Alkali - Silica Reaction", Cement and Concrete Research, Vol. 30, 2000, pp. 1063-1072, 2000.

[8] Bilodeau, A., Malhotra, V. A. "High - Volume Fly Ash System: Concrete Solution for Sustainable Development", 1st international conference on Ecological building Structure, San Rafael, California, USA, Also, ACI Materials journal, 97 (1), 97-M6, 2001.

[9] M. Anwar, I. Adam, "Sulfate Resistance and Carbonation of Fly Ash Concrete", HBRC Journal, Housing \& Building National Research Center, Giza, Egypt, Vol. 2, No. 2, pp. 7-16, August 2006. 
[10] Torii, K., Taniguchi, K., and Kawamura, M., "Sulfate Resistance of High Fly Ash Content Concrete", Cement and Concrete Research, 25(4), pp. 759-768, 1995.

[11] ACI Committee 232, "Use of Fly Ash in Concrete", ACI 232.2R-96, 1996.

[12] Antiohos, S., Maganari, K., and Tsimas, S., "Evaluation of Blends of High and Low Calcium Fly Ashes for Use as Supplementary Cementing Materials", Cement \& Concrete Composites, 27(3), pp. 349-356, 2005. 


\section{أداء خرسانة الرماد المتطاير ضد هجوم كبريتات}

الملخص

في هذا البحث تم دراسة تأثير استخدام الرماد المتطاير على مقاومة الخرسانة للكبريتات. وتعتبر الخلطات الخرسانية المستخدمة في هذه الدراسة جزءً من مشروع بحثي تناول تأثير استخدام المواد الإسمنتية الثنائية والثلاثية على الخواص المختلفة للخرسانة. وفي هذا البحث تم دراسة ثلاث مجموعات من الخلطات الخرسانية، تضم كل مجموعة منها ثلاث خلطات. تم تصميم هذه الخلطات لإنتاج خرسانة ذات قيم محددة من الهبوط ومحتوي الهواء وذلك من خلال تعديل نسب المواد المكونة للخلطة الخرسانية، وكانت نسب المياه/المواد الاسمنتية المستخدمة هي ع, • وم, • و آ, • وقد تمت معالجة العينات الخرسانية بالمياه حتى يوم الاختبار. وبعد مرور ^r يومًا من المعالجة بالمياه، تم غمر العينات في محلول كبريتات الصوديوم لمدة ج أشهر. واستخدمت الاختبارات المتلفة وغير المتلفة في تحديد خواص الخرسانة عند الاعمار المختلفة للعينات. وقد أظهرت نتائج البحث أن استخدام الرماد المتطاير يحسن مقاومة الخرسانة لهجوم الكبريتات، ولذلك يمكن استخدام الرماد المتطاير في صناعة الخرسانة لرفع أداء الخرسانة لمقاومة الكبريتات ومتانتها 